\title{
Efektifitas Teh Buah Mengkudu Dalam Menurunkan Tekanan Darah Lansia Dengan Hipertensi (Studi di UPTD. Griya Werdha Kota Surabaya Tahun 2018)
}

\section{Effectiveness Noni fruit tea In Lowering Blood Pressure Elderly With Hypertension}

Arum Reyan Safitri*, Rita Ismawati ${ }^{1}$

\begin{abstract}
ABSTRAK
Latar Belakang : Hipertensi merupakan the silent disease dimana seseorang tidak akan mengetahui jika dirinya mengalami peningkatan tekanan darah. Angka insiden hipertensi sangat tinggi terutama pada populasi lanjut usia diatas 60 tahun. Penatalaksaan hipertensi dapat dilakukan dengan cara farmakologis seperti obat-obatan serta dapat menggunakan bahan alami dalam menurunkan tekanan darah yaitu dengan memanfaatkan buah mengkudu.

Tujuan : Penelitian ini bertujuan menganalisis efektifitas teh buah mengkudu dalam menurunkan tekanan darah lansia dengan hipertensi

Metode : Penelitian ini bersifat quasy eksperimental dengan desain Pretest-Postest Control Group Design. Penentuan sampel penelitian dengan menggunakan kriteria inklusi dan eksklusi. Sampel penelitian sebanyak 34 responden yang dibagi menjadi dua kelompok. Intervensi teh buah mengkudu diberikan sebanyak 5 gram selama 30 hari dengan frekuensi pemberian 2 kali sehari pada pagi dan sore hari. Pengukuran tekanan darah darah dilakukan pada awal penelitian dan di akhir penelitian. Analisis data penelitian menggunakan uji wilcoxon dan uji Mann Whitney.

Hasil : Hasil uji Mann Whitney menunjukkan bahwa terdapat pengaruh yang signifikan sesudah intervensi teh buah mengkudu pada kelompok perlakuan dibandingkan kelompok kontrol dengan nilai tekanan darah sistolik ( $p=0.000171)$ dan tekanan darah diastolik $(p=0,000480)$ dengan $\alpha=0.05$

Kesimpulan : Tekanan darah pada kelompok perlakuan susudah intervensi teh buah mengkudu mengalami penurunan tekanan darah dibandingkan dengan kelompok kontrol. Saran penelitian, perlu dilakukan pendidikan gizi secara berkala dan pemberian teh buah mengkudu sebagai obat alternatif yang efektif menurunkan hipertensi, secara terjadwal.
\end{abstract}

Kata Kuci: teh buah mengkudu, lansia, tekanan darah 


\title{
ABSTRACT
}

Background: Hypertension is the silent disease which a person will not know if he has increased blood pressure. The incidence rate of hypertension is very high especially in the elderly population over 60 years. Hypertension management can be done in pharmacological ways such as medicines and can use natural ingredients in lowering blood pressure that is by utilizing the noni fruit.

Objectives: This study aimed to analyze the effectiveness of Noni fruit tea in lowering elderly blood pressure with hypertension

Method: This research was quasy experimental throug with Pretest-Postest Control Group Design design. Determination of research sample by using inclusion and exclusion criteria. The sample of the study was 34 respondents divided into two groups. Intervention of Noni fruit tea given as much as 5 gram for 30 days with frequency of giving 2 times a day in the morning and afternoon. Blood pressure measurement was performed at the beginning of the study and at the end of the study. Data were analysed using wilcoxon test and Mann Whitney test.

Result: Mann Whitney test results showed that there was significant effect after the intervention of noni fruit tea in treatment group compared with control group with systolic blood pressure value ( $p=$ $0.000171)$ and diastolic blood pressure $(p=0.000480)$ with $\alpha=0.05$

Conclusions: Blood pressure in the treatment group after the intervention of noni fruit tea decreased blood pressure compared with the control group. It is Suggested of research, need to do periodic nutrition education and giving noni fruit tea as alternative medicine that effectively decrease hypertension, scheduled.

Keywords: noni fruit tea, elderly, blood pressure

\author{
*Koresponden: \\ arumreyans@gmail.com \\ ${ }^{1}$ Pendidikan Tata Boga, Universitas Negeri Surabaya
}

\section{PENDAHULUAN}

Hipertensi merupakan the silent disease atau disebut juga dengan siluman pembunuh karena seeorang tidak mengetahui jika dirinya mengalami peningkatan tekanan darah, baik secara lambat maupun mendadak sebelum memeriksakan tekanan darahnya. Penyakit hipertensi juga dikatakan sebagai sebuah gejala dari sebuah sindroma yang dapat memicu terjadinya pengerasan tekanan darah sehingga menyebabkan kerusakan pada organ target seperti serangan jantung, otak (Stroke), penyakit ginjal kronik dan penyakit arteri perifer. ${ }^{1}$ Diagnosis penyakit hipertensi ditegakkan apabila tekanan darah sistole seseorang menetap di $140 \mathrm{mmHg}$ atau bisa lebih dari $140 \mathrm{mmHg}^{2}$

Penderita penyakit degeneratif merupakan hipertensi cenderung terus mengalami peningkatan. World Health
Organization (WHO) menyatakan bahwa prevalensi penderita hipertensi terus terjadi peningkatan sebanyak 839 juta kasus penderita hipertensi pada tahun 2012 dan diperkirakan akan meningkat pada tahun 2025 menjadi 1,5 miliar atau sekitar $29 \%$ dari total penduduk di seluruh dunia, Kenaikan kasus hipertensi banyak terjadi khususnya di negara berkembang seperti Indonesia sekitar $80 \%{ }^{1}$

$\mathrm{Di}$ indonesia, prevalensi hipertensi terjadi pada kelompok populasi lansia berusia diatas 60 tahun yaitu sebesar 65,4\% dan menduduki peringkat ke 5 dalam daftar penyakit yang menyebabkan kematian terutama pada golongan lanjut usia. Menurut data Riskesdas Provinsi Jawa Timur prevalensi penyakit hipertensi mencapai $26,2 \%$. Prevalensi penyakit hipertensi tertinggi terdapat pada kelompok lansia berusia $\geq 75$ tahun yaitu sebesar 62,4 \%. Prevalensi hipertensi di kota Surabaya mencapai 22,0\%. ${ }^{3}$ 
Berdasarkan hasil survey pendahuluan yang di lakukan di (Unit Pelaksana Teknis Daerah) UPTD. Griya Werdha Kota Surabaya didapatkan jumlah kasus penyakit degeneratif tertinggi menurut data angka kesakitan adalah hipertensi dengan jumlah kasus sebanyak 37 orang dari 120 lansia di UPTD. Griya Werdha Kota Surabaya.

Hipertensi pada dasarnya cenderung sulit untuk dikontrol baik dengan tindakan pengobatan dan tindakan medis dikarenakan penyakit ini memiliki sifat yang tidak stabil. Oleh karena itu perlu dilakukan suatu bentuk penanganan atau terapi. Penatalaksaan hipertensi dapat dilakukan dengan terapi fakmakologis seperti pemberian obat antihipertensi dan non farmakologis atau modifikasi gaya hidup meliputi membatasi asupan garam, penurunan berat badan berhenti merokok, olahraga rutin/aktivitas fisik dan modfikasi diet/nutrisi (terapi diet). ${ }^{2}$ Penatalaksaanan hipertensi secara terapi farmakologis ternyata masih menimbulkan keraguan dikalangan individu terutama mengenai biaya tinggi, ketidakpatuhan penderita dalam proses pengobatan ataupun persepsi keamanan suatu obat sehingga National Center for Complementary and Alternatif Medicine of The National Institude of Health telah mengklasifikasikan berbagai macam terapi dan system perawatan menjadi lima katagori. Salah satu katagorinya adalah Biological Base Therapies (BBT). BBT merupakan sebuah jenis terapi komplementer yang menggunakan bahan alam dan yang termasuk kedalam BBT adalah herbal. Beragam terapi herbal yang telah terbukti secara ilmiah dapat menurunkan tekanan darah yaitu dengan memanfaatkan menggunakan mengkudu. ${ }^{1}$

Mengkudu atau Morinda citrifolia juga disebut 'noni' digunakan selama berabad-abad sebagai obat tradisional oleh orang Polinesia selama lebih dari 2000 tahun. Berbagai komunitas di seluruh dunia mengkonsumsi buah dan daun tanaman obat tradisional ini untuk sifat terapeutiknya yang serbaguna. Morinda citrifolia ditemukan memiliki berbagai efek terapeutik seperti antiviral, antibakteri, antijamur, antitumor, anthelmintik, analgesik, hipotensi, anti- inflamasi, efek peningkatan kekebalan tubuh, mencegah penurunan kolesterol dalam tubuh, zat antihipetensi yaitu zat scopoletin berfungsi mencegah pembentukan plak (aterosklerosis) serta dapat menurunkan tekanan darah. ${ }^{4}$

Berdasarkan penelitian yang dilakukan pemberikan intervensi jus mengkudu selama 5 hari sebanyak 1 buah (100g) pada kelompok usia lanjut di Unit Rehabilitasi Sosial Margo Rembang dengan hipertensi ternyata terdapat selisih terhadap penurunan tekanan darah sebelum dan setelah dilakukan intervensi dengan jus mengkudu. ${ }^{5}$ Penelitian lainnya menunjukkan adanya perbedaan tekanan darah sistolik dan diastolik pada kelompok eksperimen dan kontrol wanita penderita hipertensi di Panti Wredha Pucang Gading Semarang sebelum sesudah dilakukan terapi minuman buah mengkudu selama 14 hari. $^{6}$ Pemberian kapsul ekstrak mengkudu secara rutin sebayak 60 kapsul selama 15 hari dapat menurunkan tekanan darah pada kelompok usia lanjut. ${ }^{7}$ Selain itu, terapi minuman mengkudu pada penderita hipertensi ternyata dapat menurunkan tekanan darah yang nyata setelah diberikan terapi tersebut. ${ }^{8}$ Buah mengkudu yang dibuat teh berupa serbuk dengan penambahan teh hitam dan vitamin C dapat dijadikan sebagai alternatif minuman kesehatan. ${ }^{9}$

Penelitian ini bertujuan untuk menganalisis efektifitas teh buah mengkudu dalam menurunkan tekanan darah lansia dengan hipertensi.

\section{METODE}

Penelitian ini merupakan jenis penelitian quasy eksperimental. Desain studi penelitian pretest-postest control group design. Populasi penelitian ini adalah semua lansia penderita hipertensi berusia 60 tahun ke atas di UPTD. Griya Werdha Kota Surabaya Tahun 2018. Cara penentuan sampel dengan menggunakan kriteria inklusi dan eksklusi dan dibagi menjadi dua kelompok yaitu kelompok perlakuan dan kelompok kontrol. Kriteria inklusi penelitian ini adalah penderita hipertensi berusia $>60$ tahun, tidak mengkonsumsi obat farmakologis, tekanan darah $>140 / 90 \mathrm{mmHg}$, tidak merokok, tidak 
mengalami obesitas, tidak mengkonsumsi kopi, bersedia menjadi responden penelitian, sedangkan kriteria eksklusi penelitian ini adalah tidak bersedia menjadi responden, memiliki penyakit yang dapat mempengaruhi hipertensi (diabetes, asam urat, obesitas, gagal ginjal), responden drop out. Teknik pengambilan data menggunakan simple random sampling. Pengambilan sampel dilakukan secara acak melalui pengambilan nomor yang telah ditulis, sampel terdiri dari 17 kelompok perlakuan dan 17 kelompok kontrol dengan jumlah sampel keseluruhan 34 sampel.

Lokasi penelitian di UPTD. Griya Werdha Kota Surabaya. Pengambilan data dilakukan pada bulan Februari-Maret 2018. Variabel dependen dalam penelitian ini adalah tekanan darah sedangkan variabel independen dalam penelitian ini adalah teh buah mengkudu.

Cara pembuatan teh buah mengkudu dalam penelitian ini dilakukan melalui proses sortasi ,pencucian, pemotongan, dan pengeringan dengan sinar matahari selama 23 hari dan bahan baku teh yang digunakan adalah buah mengkudu dengan tingkat kematangan sedang dengan ciri-ciri buah berwarna putih kekuningan, daging buah keras, dan tidak berbau.

Intervensi teh buah mengkudu dengan dosis 5 gram teh buah mengkudu kering diseduh menggunakan air (200cc) selama 5 menit dengan suhu air $70-90^{\circ} \mathrm{C}$ dan ditambahkan 1 potongan kecil kayu manis $(2 \mathrm{~cm})$ yang telah disangrai kemudian ditambahkan dengan gula batu sebanyak 1 gram. Kayu manis dalam penelitian ini hanya sebagai penetralisir atau penghilang aroma khas dari buah mengkudu tanpa mengurangi manfaat dan kandungan dalam teh buah mengkudu. Teh buah mengkudu diberikan selama 1 bulan (30 hari) sebanyak 2 kali dalam satu hari pada pagi dan sore hari. ${ }^{10}$

Uji kelayakan teh buah mengkudu dalam penelitian ini telah dilakukan berdasarkan uji panelis terbatas yang terdiri dari panelis terlatih dan panelis tidak terlatih. Uji kelayakan teh buah mengkudu dilakukan dengan uji organoleptik yang meliputi warna, bau, rasa, aroma, dan kekeruhan. Berdasarkan uji organoleptik didapatkan bahwa teh buah mengkudu dapat diterima oleh panelis terlatih dan panelis tidak terlatih dan layak dikonsumsi. Teh buah mengkudu dalam penelitian ini berdasarkan uji organoleptik berwarna merah kecoklatan, tidak berbau, rasa enak, aroma khas mengkudu tidak terlalu dominan dan tidak keruh/ jernih seperti teh.

Pengukuran tekanan darah pada lansia dilakukan di awal penelitian (pretest) dan dilakukan pengukuran tekanan darah kembali di akhir penelitian (postest) dengan menggunakan alat tensimeter jenis tensi Aneroid ABN Spectrum. Pengukuran tekanan darah dilakukan oleh tenaga medis yaitu perawat dengan posisi pengukuran dalam keadaan duduk tenang dan pengukuran tekanan darah dilakukan pada pagi hari.

Uji etik dilakukan di ruang etik Fakultas Kesehatan Masyarakat Universitas Airlangga, tanggal 05 Januari 2018 dengan no.07-KEPK. Analisis data menggunakan uji Wilcoxon untuk menguji perbedaan tekanan darah pada masing-masing kelompok perlakuan dan kelompok kontrol sebelum dan sesudah intervensi teh buah mengkudu. Uji Mann Whitney digunakan untuk menguji perbedaan tekanan darah pada kelompok perlakuan dengan kelompok kontrol sesudah pemberian teh buah mengkudu dengan $p<0.05$ maka Ho diterima yang berarti terdapat pengaruh yang bermakna terhadap penurunan tekanan darah.

\section{HASIL DAN PEMBAHASAN}

Berdasarkan hasil penelitian pada tabel 1 menujukkan bahwa sebagian besar lansia pada kelompok perlakuan perlakuan dan kelompok kontrol termasuk dalam kategori usia lanjut dan usia lanjut tua. Faktor usia sangat berpengaruh terhadap kejadian hipertensi dan semakin bertambahnya umur maka semakin beresiko mengalami hipertensi. Hipertensi pada lanjut usia atau lansia disebabkan oleh perubahan yang secara alamiah di dalam tubuh yang dapat mempengaruhi cara kerja jantung, pembuluh darah dan hormon, sehingga terjadi beberapa perubahan fisiologis yaitu terjadi peningkatan tekanan resistensi perifer dan aktivitas 
Tabel 1. Distribusi Frekuensi Berdasarkan Umur Lansia di UPTD.Griya Werdha

\begin{tabular}{lcccc}
\hline \multirow{2}{*}{ Kategori Umur } & \multicolumn{2}{c}{ Perlakuan } & \multicolumn{2}{c}{ Kontrol } \\
\cline { 2 - 5 } & $\mathbf{n}$ & $\%$ & $\mathbf{n}$ & $\%$ \\
\hline Usia lanjut (Elderly) & 13 & 76,47 & 7 & 41,18 \\
Usia lanjut tua (Old) & 4 & 23,53 & 10 & 58,82 \\
Usia sangat tua (Very old) & 0 & 0 & 0 & 0 \\
\hline
\end{tabular}

Tabel 2. Distribusi Frekuensi Berdasarkan Jenis Kelamin Lansia di UPTD. Griya Werdha

\begin{tabular}{lcccc}
\hline \multirow{2}{*}{ Jenis Kelamin } & \multicolumn{2}{c}{ Perlakuan } & Kontrol \\
\cline { 2 - 5 } & $\mathbf{n}$ & $\mathbf{n}$ & $\mathbf{n}$ & \% \\
\hline Laki-laki & 4 & 23,56 & 4 & 23,56 \\
Perempuan & 13 & 76,44 & 13 & 76,44 \\
\hline
\end{tabular}

Tabel 3. Tekanan Darah Sebelum Dan Sesudah Pada Kelompok Kontrol

\begin{tabular}{|c|c|c|c|c|c|c|c|c|c|c|}
\hline \multirow{4}{*}{$\begin{array}{l}\text { Kategori } \\
\text { Hipertensi }\end{array}$} & \multicolumn{10}{|c|}{ Kontrol } \\
\hline & \multicolumn{4}{|c|}{ Sebelum } & \multicolumn{4}{|c|}{ Sesudah } & \multicolumn{2}{|c|}{$p$-value } \\
\hline & \multicolumn{2}{|c|}{ Sistolik } & \multicolumn{2}{|c|}{ Diastolik } & \multicolumn{2}{|c|}{ Sistolik } & \multicolumn{2}{|c|}{ Diastolik } & \multirow{2}{*}{ Sistolik } & \multirow{2}{*}{ Diastolik } \\
\hline & $n$ & $\%$ & $n$ & $\%$ & $n$ & $\%$ & $\mathbf{n}$ & $\%$ & & \\
\hline Normal & 0 & 0 & 0 & 0 & 0 & 0 & 1 & 5.88 & & \\
\hline $\begin{array}{l}\text { Hipertensi } \\
\text { ringan }\end{array}$ & 8 & 47.06 & 9 & 52.94 & 6 & 35.29 & 5 & 29.41 & & \\
\hline $\begin{array}{l}\text { Hipertensi } \\
\text { sedang }\end{array}$ & 9 & 52.94 & 8 & 47.06 & 11 & 64.71 & 11 & 64,71 & $p=$ & $p=$ \\
\hline $\begin{array}{l}\text { Hipertensi } \\
\text { berat }\end{array}$ & 0 & 0 & 0 & 0 & 0 & 0 & 0 & 0 & 0.059 & 0.577 \\
\hline $\begin{array}{c}\text { Hipertensi } \\
\text { sangat } \\
\text { berat }\end{array}$ & 0 & 0 & 0 & 0 & 0 & 0 & 0 & 0 & & \\
\hline
\end{tabular}

Tabel 4. Tekanan Darah Sebelum Dan Sesudah Pada Kelompok Perlakuan

\begin{tabular}{|c|c|c|c|c|c|c|c|c|c|c|}
\hline \multirow{4}{*}{$\begin{array}{l}\text { Kategori } \\
\text { Hipertensi }\end{array}$} & \multicolumn{8}{|c|}{ Perlakuan } & \multirow{2}{*}{\multicolumn{2}{|c|}{$p$-value }} \\
\hline & \multicolumn{4}{|c|}{ Sebelum } & \multicolumn{4}{|c|}{ Sesudah } & & \\
\hline & \multicolumn{2}{|c|}{ Sistolik } & \multicolumn{2}{|c|}{ Diastolik } & \multicolumn{2}{|c|}{ Sistolik } & \multicolumn{2}{|c|}{ Diastolik } & \multirow{2}{*}{ Sistolik } & \multirow{2}{*}{ Diastolik } \\
\hline & $\mathrm{n}$ & $\%$ & $n$ & $\%$ & $n$ & $\%$ & $n$ & $\%$ & & \\
\hline Normal & 0 & 0 & 0 & 0 & 13 & 76.47 & 13 & 76.47 & & \\
\hline $\begin{array}{l}\text { Hipertensi } \\
\text { ringan }\end{array}$ & 7 & 41.18 & 7 & 41.18 & 0 & 0 & 0 & 0 & & \\
\hline $\begin{array}{l}\text { Hipertensi } \\
\text { sedang }\end{array}$ & 10 & 58.82 & 10 & 58.82 & 4 & 23.53 & 4 & 23.53 & $p=$ & $p=$ \\
\hline $\begin{array}{l}\text { Hipertensi } \\
\text { berat }\end{array}$ & 0 & 0 & 0 & 0 & 0 & 0 & 0 & 0 & 0.001 & 0.002 \\
\hline $\begin{array}{c}\text { Hipertensi } \\
\text { sangat } \\
\text { berat }\end{array}$ & 0 & 0 & 0 & 0 & 0 & 0 & 0 & 0 & & \\
\hline
\end{tabular}


Tabel 5. Tekanan Darah Sesudah Intervensi Pada Kelompok Kontrol dan Kelompok Perlakuan

\begin{tabular}{|c|c|c|c|c|c|c|c|c|c|c|}
\hline \multirow{4}{*}{$\begin{array}{l}\text { Kategori } \\
\text { Hipertensi }\end{array}$} & \multirow{2}{*}{\multicolumn{4}{|c|}{$\begin{array}{l}\text { Kontrol } \\
\text { Sesudah }\end{array}$}} & \multirow{2}{*}{\multicolumn{4}{|c|}{$\begin{array}{l}\text { Perlakuan } \\
\text { Sesudah }\end{array}$}} & \multirow{2}{*}{\multicolumn{2}{|c|}{$p$-value }} \\
\hline & & & & & & & & & & \\
\hline & \multicolumn{2}{|c|}{ Sistolik } & \multicolumn{2}{|c|}{ Diastolik } & \multicolumn{2}{|c|}{ Sistolik } & \multicolumn{2}{|c|}{ Diastolik } & \multirow{2}{*}{ Sistolik } & \multirow{2}{*}{ Diastolik } \\
\hline & $\mathbf{n}$ & $\%$ & $n$ & $\%$ & $n$ & $\%$ & $n$ & $\%$ & & \\
\hline Normal & 0 & 0 & 1 & 5.88 & 13 & 76.47 & 13 & 76.47 & & \\
\hline $\begin{array}{l}\text { Hipertensi } \\
\text { ringan }\end{array}$ & 6 & 35.29 & 5 & 29.41 & 0 & 0 & 0 & 0 & & \\
\hline $\begin{array}{l}\text { Hipertensi } \\
\text { sedang }\end{array}$ & 11 & 64.71 & 11 & 64,71 & 4 & 23.53 & 4 & 23.53 & $p=$ & $p=$ \\
\hline $\begin{array}{l}\text { Hipertensi } \\
\text { berat }\end{array}$ & 0 & 0 & 0 & 0 & 0 & 0 & 0 & 0 & 0.000171 & 0.000480 \\
\hline $\begin{array}{c}\text { Hipertensi } \\
\text { sangat } \\
\text { berat }\end{array}$ & 0 & 0 & 0 & 0 & 0 & 0 & 0 & 0 & & \\
\hline
\end{tabular}

simpatik serta dinding arteri akan mengalami perubahan penebalan karena ada penumpukan zat kolagen pada lapisan otot yang menyebabkan pembuluh darah mengalami penyempitan dan kekakuan. ${ }^{11}$ Berdasarkan hasil penelitian pada tabel 2 menunjukkan bahwa sebagian besar lansia pada kelompok perlakuan dan kelompok kontrol berjenis kelamin perempuan. Menurut Kumar, perempuan pada masa menopouse kehilangan hormon seks ekstrogen yang berfungsi melindungi saluran pembuluh darah yang mengalami kerusakan karena hormon seks estorgen akan menghasilkan peningkatan kadar High Density Lipoprotein / HDL yang akan mencegah terjadinya proses aterosklerosis. ${ }^{11}$

Berdasarkan hasil penelitian pada tabel 3 menunjukkan bahwa sebagian besar lansia pada kelompok kontrol sebelum dan sesudah tanpa intervensi pemberian teh buah mengkudu tekanan darah sistole lansia berada pada kategori hipertensi sedang, sedangkan tekanan darh diastolik lansia berada pada kategori hipertensi ringan dan hipertensi sedang. Hasil analisa data tekanan darah sebelum dan sesudah menggunakan uji wilcoxon didaptkan nilai $p$ value sistole $=$ $0.059, p$ value diastolik $=0.577$ yang berarti bahwa tidak ada beda tekanan darah sistolik dan diastolik sebelum dan sesudah pada kelompok kontrol.

Berdasarkan tebel 4 menunjukkan bahwa sebagian besar lansia pada kelompok perlakuan sebelum intervensi teh buah mengkudu tekanan darah sistolik dan diastolik berada pada kategori hipertensi sedang, sedangkan setelah intervensi tekanan darah lansia baik sistolik dan diastolik berada pada kategori normal. Hasil analisa data tekanan darah sebelum dan susudah menggunakan uji wilcoxon didapatkan nilai $p$ value sistolik $=$ $0.001, p$ value diastolik $=0,002$ yang berarti bahwa ada beda tekanan darah sistolik dan diastolik sebelum dan sesudah pada kelompok perlakuan.

Berdasarkan tabel 5 menunjukkan bahwa sebagian besar lansia pada kelompok perlakuan sesudah intervensi teh buah mengkudu tekanan darah sistolik dan diastolik berada pada kategori normal, sedangkan tekanan darah sistolik dan diastolik sesudah tanpa intervensi teh buah mengkudu (kelompok kontrol) sebagian besar lansia berada pada kategori hipertensi sedang. Hasil uji analisa data tekanan darah sesudah intervensi pada kelompok kontrol dengan kelompok perlakuan menggunakan uji Mann Whitney didapatkan nilai $p$ value sistolik = $0.000171, p$ value diastolik $=0.000480$ yang berarti bahwa ada pengaruh intervensi pemberian teh buah mengkudu dalam menurunkan tekanan darah pada lansia yang mengalami hipertensi dibandingkan dengan kelompok tanpa intervensi teh buah mengkudu.

Hipertensi pada kelompok lansia disebut dengan hipertensi sistolik dimana dalam hal ini semakin bertambahnya usia seseorang akan mengalami kenaikan tekanan 
darah karena pada usia lanjut terjadi penebalan dan kekakuan pada dinding arteri yang disebabkan oleh arterosklerosis sehingga jantung harus bekerja secara keras untuk memompa darah dengan keadaan pembuluh darah yang mengalami penyempitan, maka hal ini akan menyebabkan tekanan darah menjadi naik. Tekanan darah sistolik akan mengalami peningkatan sampai usia 80 tahun sedangkan tekanan darah diastolik akan mengalami peningkatan samapi berusia 55-60 tahun. ${ }^{1}$

Teh buah mengkudu sebanyak 5 gram dalam penelitian ini terbukti dapat dijadikan sebagai alternatif pengobatan tradisional serta efektif dalam menurunkan tekanan darah sistolik sebesar $26 \%$ dan diastolik sebesar $20 \%$ pada kelompok lansia dengan hipertensi di UPTD. Griya Werdha Jambangan Kota Surabaya. Buah mengkudu banyak mengandung zat kimia yang sangat berguna bagi tubuh diantaranya adalah senyawa Terpenoid, Zat asam (askorbat, kaproat, karpitat), Zat antibakteri (Acubin, L.asperuloside, alizarin, antraquinon), Nutrisi (karbohidrat, protein, vitamin, mineral esensial), Zat anti kanker (damnacanthal), Zat Scopoletin (antihipertensi). ${ }^{12}$

Kandungan buah mengkudu yang dapat menurunkan tekanan darah adalah Scopoletin. Zat Scopoletin dalam buah mengkudu ditemukan pada tahun 1993 oleh para peneliti di Universitas Hawaii. Scopoletin berfungsi memperlebar saluran pembuluh darah yang mengalami penyempitan serta melancarkan peredaran darah. ${ }^{12}$ Kandungan scopoletin buah mengkudu dalam 1 gram adalah sebesar 290,02 ppm. ${ }^{13}$

Scopoletin dapat menurunkan tekanan darah dengan cara menurunkan tahanan atau resistensi perifer. Besarnya tahanan perifer bergantung pada kontraktilitas otot polos pembuluh darah. Kontraktilitas otot polos pembuluh darah dipengaruhi oleh fungsi endotel pembuluh darah, karena pada endotel disintesis dan disekresi berbagai bahan vasokonstriktor dan vasodilator. ${ }^{14,15}$ Kandungan bahan aktif scopoletin dalam mengkudu memiliki fungsi dalam menormalkan tekanan darah dengan adanya efek spasmolitik yaitu efek yang mempunyai kemampuan serupa dengan cara kerja obat antihipertensi. Efek spasmolitik ditandai dengan terjadinya pelebaran pembuluh darah (vasodilatasi) akibat relaksasi otot polos. Otot polos pembuluh darah diatur oleh sistem syaraf simpatis melalui pengeluaran neurotransmiter noradrenalin di ujung syaraf simpatis pada dinding pembuluh darah sehingga otot polos direlaksasi oleh zat scopoletin yang berfungsi sebagai vasodilator. ${ }^{16}$

Scopoletin adalah salah satu zat yang terkandung di dalam buah mengkudu. Scopoletin merupakan senyawa fenol yang memliki titih didih $356^{\circ} \mathrm{C} .{ }^{17}$ Pada Penelitian Setyaningsih, cacahan buah mengkudu yang dikeringkan dan diseduh dengan air panas mampu menurunkan hipertensi secara signifikan $(p<0,05){ }^{6}$ Hal ini sejalan dengan penelitian yang dilakukan pada buah mengkudu yang dijadikan seduhan teh secara signifikan $(p<0,05)$ mampu menurunkan hipertensi pada lansia.

Kandungan kadar scopoletin yang sangat tinggi terdapat pada buah mengkudu dengan tingkat kematangan yang sedang dan sangat baik digunakan sebagai bahan pengobatan tradisional dan bahan baku sediaan fitofarmaka. Dalam penelitian yang dilakukan di UPTD. Griya Werdha bahan baku teh mengkudu menggunakan buah dengan tingkat kematangan sedang. Berdasarkan penelitian lainnya tentang pengukuran kandungan scopoletin pada buah mengkudu pada beberapa tingkat kematangan buah menggunakan metode KLT-densinometri didapatkan hasil bahwa kadar scopoletin paling tinggi terdapat pada buah dengan tingkat kematangan sedang dengan umur 105 hari yaitu sebesar $57,94 \pm 0,79 \mathrm{ppm}$ dengan ciri ciri kulit buah berwarna putih-putih kekuningan dan buah berdaging keras. Kadar scopoletin akan mengalami peningkatan sampai buah berumur 105 hari dan akan mengalami penurunan kadar setelah melewati usia tersebut. ${ }^{13}$

Keterbatasan penelitian ini adalah peneliti tidak mengukur atau meneliti faktor lingkungan pada responden penelitian. Faktor lingkungan seperti stres pada masing-masing individu, dimana stres dapat memicu 
terjadinya hipertensi karena adanya peningkatan saraf simpatis sehingga hal ini dapat meningkatkan tekanan darah secara intermitten atau tidak menentu. Saraf simpatis merupakan saraf yang bekerja di saat tubuh kita melakukan sebuah aktivitas. Apabila stres yang dialami seorang induvidu berkepanjangan maka akan mengakibatkan tekanan darah menetap dan tinggi. Stres atau rasa takut menyebabkan tekanan arteri dalam darah meningkat sebanyak dua kali dari normal dalam waktu beberapa detik. ${ }^{1}$

\section{KESIMPULAN}

Kesimpulan dari penelitian ini adalah terdapat penurunan tekanan darah sistole maupun diastole pada kelompok perlakuan sesudah intervensi dengan teh buah mengkudu dibandingkan dengan kelompok kontrol. Perlu meningkatkan pemberian bahan alami yang efektif sebagai pengobatan hipertensi pada lansia.

\section{ACKNOWLEDGMENT}

Ucapan terimakasih penulis sampaikan kepada Dinas Sosial Kota Surabaya dan kepala UPTD. Griya Werdha Kota Surabaya yang telah mengijinkan melakukan penelitian di unit pelayanan sosial tersebut.

\section{REFERENSI}

1. Triyanto, E. Pelayanan Keperawatan Bagi Penderita Hipertensi Secara Terpadu. (Graha Ilmu, 2014).

2. Pikir, B. S. et al. Hipertensi: Manajemen Komprehensif. (Airlangga University Press, 2015).

3. Trihono Trihono. Riset Kesehatan Dasar (RISKESDAS) 2013. Laporan Nasional 2013 (2013).

4. Nagalingam, S., Sasikumar, C. S. \& Cherian, K. M. Morinda citrifolia (Noni) - A Detailed Review. Int. J. Univers. Pharm. Bio Sci. 6, 494-509 (2013).

5. Megawati, A. \& Hidayat, F. D. Pengaruh Jus Mengkudu Terhadap Penurunan Tekanan Darah Pada Lanjut Usia Dengan Hipertensi di Unit Rehabilitasi Sosial
Margo Mukti Rembang. J. Keperawatan dan Kesehat. Masy. Cendekia Utama 2, 75-90 (2015).

6. Setyaningsih, S. E. Perbedaan Tekanan Darah Sebelum dan Sesudah Terapi Mengkudu pada Wanita Penderita Hipertensi (Studi Kasus di Panti Wredha Pucang Gading Semarang Tahun 2010). (2011).

7. Indriawati, R. \& Hartono, I. S. E. Pengaruh Mengkudu (Morinda citrifolia) terhadap Hipertensi pada Kelompok Usia Lanjut. Mutiara Med. 11, 167-174 (2011).

8. Suidah, H. Pengaruh Mengkudu Terhadap Penurunan Tekanan Darah Pada Penderita Hipertensi Di Desa Wedoroklurak Kecamatan Candi Kabupaten Sidoarjo. J. Keperawatan 01, 9 (2011).

9. Septiyani, R. et al. Minuman Kesehatan Teh Mengkudu Instan Dengan Penambahan Vitamin C. Universitas Gadjah Mada 15-17 (2003).

10. Handayani, L. \& Budijanto, D. Efek Ramuan Buah Mengkudu dan Daun Kumis Kucing untuk Menurunkan Tekanan Darah pada Penderita Hipertensi. (Cermin Dunia Kedokteran, 1997).

11. Kumar, V., Abbas, A. K. \& Aster, J. C. Robbins and Cotran Pathologic Basis of Disease. (Elsevier Inc, 2015).

12. Dewi, N. Budidaya, Khasiat dan Cara Olah Mengkudu Untuk Mengobati Berbagai Penyakit. (Pustaka Baru Press, 2012).

13. Sholehah, D. N. Pengukuran Kandungan Skopoletin pada Beberapa Tingkat Kematangan Buah Mengkudu (Morinda citrifolia Linn) dengan Metode KLT Densitometri. Agrovigor 3, 1-9 (2010).

14. Katzung, B. G. Basic \& Clinical Pharmacology. (McGraw-Hill Education, 2018).

15. Hidayat, T., Wahyuni, E. S. \& Karyono, S. S. Pengaruh Ekstrak Buah Mengkudu ( Morinda citrifolia ) Terhadap Aorta Terpisah Marmut ( Cavia porcellus ) Tanpa Endotel. J. Kedokt. Brawijaya 19, 120-124 (2003). 
16. Sjabana, D. \& Bahalwan, R. R. Pesona Tradisional dan Ilmiah Mengkudu. (Salemba Medika, 2002).
17. Harborne, J. B. Phytochemical Methods: A Guide to Modern Techniques of Plant Analysis. (Chapman and Hall, 1984). doi:10.1007/978-94-009-5570-7 